\title{
АСПЕКТИ НА ПРИДАВСКАТА СЕКУНДАРНА ПРЕДИКАЦИЈА ВО МАКЕДОНСКИОТ ЈАЗИК
}

\author{
Бојан Петревски \\ Универзитет „Св. Кирил и Методиј“, Скопје \\ bojan_petrevski@yahoo.com
}

Во трудот се посочуваат основните карактеристики на придавската секундарна предикација во македонскиот јазик. Проблемот се разгледува, пред сѐ, од семантички и од синтаксички аспект, но и на планот на информациската структура. Се изделуваат основните значења на придавките во таа функција, врската меѓ н нивниот карактер од аспект на тематско-рематската структура и позицијата во исказот и причините за нивната интегрираност или неинтегрираност во прозодиската структура. Во таа смисла, се посочува кога влегуваат во релација што е само временски паралелна со примарната предикација, од една страна, и со дополнителна, каузална нијанса, од друга; во кои случаи се јавуваат во информациското јадро или надвор од него во зоната десно или лево од предикатот; какви импликации има нивниот информациски карактер во поглед на позицијата; како се одразува разликата помеѓу депиктивните секундарни предикати и придавските елементи што изразуваат подолготрајни карактеристики. Примерите се ексцерпирани од неколку книжевни дела.

Клучни зборови: придавка, секундарна предикација, актуелен атрибут, значење, позиција 


\title{
ASPECTS OF ADJECTIVAL SECONDARY PREDICATION IN MACEDONIAN
}

\author{
Bojan Petrevski \\ Ss. Cyril and Methoduis University, Skopje \\ bojan_petrevski@yahoo.com
}

The paper discusses the basic features of the adjectival secondary predication in Macedonian. It focuses on several aspects, especially on the semantic, syntactic and information structure character of the secondary predicates. In that regard, the paper points out their basic meanings, the relation between the thematic structure and their position in the utterance, as well as the reasons for their embeddedness or non-embeddedness in the prosodic structure. Several features are detected: the temporal and the causal character of their relation with the primary predication; the cases in which they occur within or out of the informational core (in the zone right or left from the predicate); the implications of their informational character regarding the position; and the reflection of the difference between depictive secondary predicates and adjectives expressing longstanding characteristics. The analysis is carried out, mainly, by drawing on examples collected from literary works by several Macedonian authors.

Keywords: adjective, secondary predication, depictive, meaning, position 


\section{1 Вовед}

Во овој труд ќе бидат разгледани придавките во функција на секундарни предикати, кои се носители на предикација што, во форма на редуцирана пропозиција, се додава на примарната (Combettes 1998: 137). Станува збор за конструкциите од типот на Се врайија охрабрени, кои може да добијат и повеќе од една интепретација, но и да се јават во повеќе позициски и про-

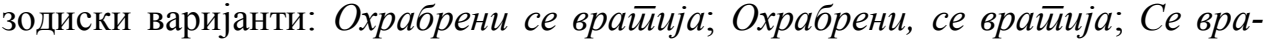
йија, охрабрени.

Целта на трудот е да покаже кои се основните значења на секундарните предикати, каков е нивниот карактер на планот на информациската структура и како се рефлектира на нивната позиција во исказот и на тоа што во некои случаи се интегрирани во прозодиската структура, а во некои - неинтегрирани. Притоа, се застапува тезата дека во повеќето случаи посочуваат карактеристика паралелна на примарната предикација и ја заземаат финалната позиција, а интегрираноста или неинтегрираноста во прозодиската структура зависи од тоа дали функционираат како основна или како дополнителна информација. Примерите што ќе бидат разгледани се, главно, ексцерпирани од неколку книжевни дела (РБ - Мојот̄ маж од Румена Бужаровска, БК - Дневник йо многуу г̄ояини од Блаже Конески, ДС - Мрйва йрка од Димитар Солев, ВМ - Небо без sвезои од Владимир Мартиновски).

\section{2 Придавската секундарна предикација од семантички аспект}

\section{1 Придавките како актуелни атрибути/депиктивни секундарни предикати}

Што се однесува на македонистичката литература, Минова-Ѓуркова (2000: 221) ја разгледува таа функција како дел од „предикативниот атрибут“, за кој посочува дека може да биде интегриран (вклопен во прозодиската структура на исказот) и неинтегриран (издвоен). Меѓу другите, ги наведува следниве примери што се вклопуваат во дефиницијата на конструкциите што тука ќе се разгледуваат како актуелни атрибути: интегрирани (1), (2), (3); неинтегрирани (4), (5).

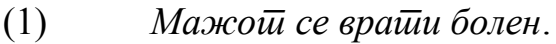

(2) Ја остиави яевојкайа замислена.

(3) Пејачой се заблаг̄ояари вияливо возбуяен и среќен.

(4) Зая нив, йоэзнайо, стиои еяно яетее.

(5) Осамен и осииавен оя сииее, сииарецой набрзо се разболе.

Тука се разгледуваат со следниве интерпретации: 'кога се врати, мажот беше болен', ‘кога ја остави девојката, беше замислена', 'кога се заблагодари, 
пејачот беше видливо возбуден и среќен', 'зад нив стои едно дете, при што е подзинато', 'старецот набрзо се разболе, при што беше осамен и оставен од сите'. ${ }^{1}$

Тополињска (1997: 96) ги сместува конструкциите што тука ќе се разгледуваат како актуелни атрибути во рамките на „реченичните трансформи“" (еквиваленти на дел-реченици). Во врска со глаголските придавки, посочува дека тие примарно функционираат како определби во именската синтагма, а не како додатоци кон предикативниот израз (за разлика од глаголските прилози), па дека затоа во многу случаи трансформите со нив може да имаат двојна интерпретација, односно, освен во врска со целиот исказ, да се толкуваат и како дел од именската синтагма (т.е. во врска со еден од именските аргументски изрази во исказот). Во таа смисла, за примерот (6) посочува две парафрази: 'Иван, кој беше потпрен на вратата, ја следеше дискусијата' и 'Иван беше потпрен на вратата и ја следеше дискусијата', од кои втората се вклопува во функцијата на „темпорална реченична трансформа“, со значење на паралелност во однос на главниот настан.

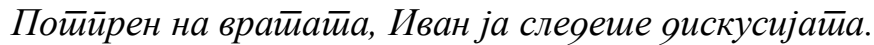

Клучен за овој труд е поимот акйуелен айрибуй (яейикииивен секуняарен $\bar{u} p e g u \kappa a \bar{u})$, со кој се опфаќаат придавските елементи што му припишуваат на носителот карактеристика актуелна во интервалот на настанот (7), (8).

$$
\text { Чекаме замислен. ('додека чекаше, беше замислен') }
$$

$$
\text { Говореме г̄невен. (‘додека говореше, беше гневен’) }
$$

Исказите во кои се содржат функционираат како одговори на прашањето Каков е яояека го йрави йоа?. Во широка смисла, тие може да се парафразираат како 'додека го прави тоа, тој е таков' ('тој го прави тоа, при што е

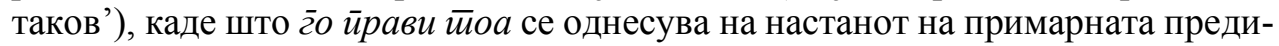
кација, йаков - на карактеристиката паралелна со него, а $\bar{u} о j-$ на нејзиниот носител.

Така, за разлика од тие случаи, во (9) е најверојатно да се претпостави контекст во кој заяоволен е рестриктивен модификатор (дел од именската синтагма), при што од сите професори го идентификува тој што бил задоволен ('конференцијата ја отвори тој професор што беше задоволен, а не другите'). Сепак, не е исклучена ни нерестриктивната интерпретација: 'професорот, кој беше задоволен, ја отвори конференцијата', затоа што рестриктивната и нерестриктивната функција не мора да бидат формално издиференцирани една од друга, како што посочува, на пример, Менгено (Maingueneau

\footnotetext{
${ }^{1}$ Последниот пример е двозначен. Освен како актуелен атрибут ('старецот набрзо се разболе, при што беше осамен и оставен од сите'), може да се толкува и причински ('бидејќи беше осамен и оставен од сите, старецот набрзо се разболе').
} 
2014: 79-80). Како и да е, и во едниот и во другиот случај придавката е дел од именската синтагма.

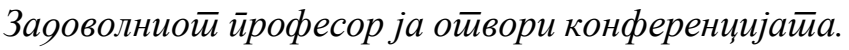

Од друга страна, во (10) е актуелен атрибут, дел од реченичната структура, при што на веќе идентификуваниот референт му припишува дополнителна карактеристика, актуелна во моментот на настанот ('кога ја отвори конференцијата, професорот беше задоволен'), т.е. одговара на прашањето Каков беше

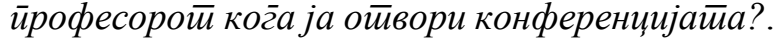

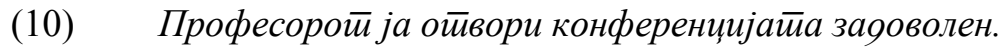

Ноели (Noailly 1999: 115-117) го употребува во таа смисла терминот

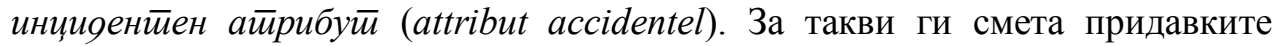
сместени по предикат конституиран од полнозначен, некопулативен глагол, од типот на (11) и (12).

(11) Blaise part tranquille.

'Блез заминува мирна.'

(12) Lise est sortie très émue.

'Лиз излезе многу возбудена.'

Придавките во таа функција тој не ги разгледува како синтаксички неопходни, туку како атрибутивно проширување, ${ }^{2}$ а глаголите со кои се употребени - како „оказионално атрибутивни“. Во таа смисла, во тие случаи глаголот го задржува своето значење, т.е. останува полнозначен. Како најчести примери во граматичките описи на францускиот јазик ги посочува умира млая (стйар), живее среќен, заминува бесен (смирен), засииива заяоволен.

Химелман и Шулц-Бернт (Himmelmann and Schultze-Berndt 2005) посочуваат дека како синонимни на терминот секуноарен йреgикай се употребуваат

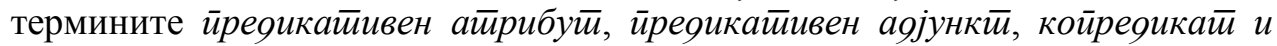
койреоикайив. Притоа, наведуваат дека секундарните предикати се класификуваат, главно, на депиктивни (depictive) и резултативни (resultative). Депиктивните, кои се однесуваат на состојби што траат во интервалот на настанот на главниот предикат, ги илустрираат со примерите (13) и (14).

Claire left the room angry.

'Клер ја напушти собата лута.'

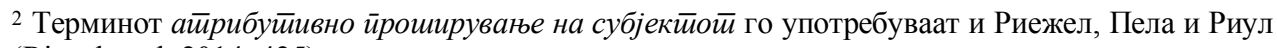
(Riegel et al. 2014: 425). 
(14) George bought the carrots fresh.

'Џорџ ги купи морковите свежи.'

Како што се согледува, во првиот пример секундарниот предикат се однесува на субјектот, а во вториот - на директниот објект. Во врска со директниот објект, секундарната предикација може да биде и резултативна, за која го посочуваат примерот (15), каде што ровкоста не е паралелна со настанот на примарниот предикат, туку произлегува од него.

George boiled the carrots soft.

'Џорџ ги свари морковите ровки.'

Во овој труд интересот ќ се ограничи на актуелните атрибути (депиктивните секундарни предикати) во врска со субјектот. Случаите во кои се однесуваат на другите синтаксички функции бараат одделна, поопширна анализа.

\section{2 Конструкции што изразуваат карактеристика паралелна на настанот без дополнителни значења}

Од семантички аспект, конструкциите може да бидат во неколку типа релации со примарната предикација. Најчести се случаите во кои изразуваат карактеристика паралелна на главниот настан без дополнителни (каузални) нијанси (16), (17), (18).

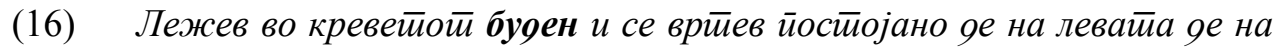
gеснайа сиирана. (БК, 127) ('додека лежев во креветот, бев буден')

(17) Дано навистиина учеше сеянай на својайа маса (...) (ДС, 26) ('додека учеше, Дано беше седнат на својата маса')

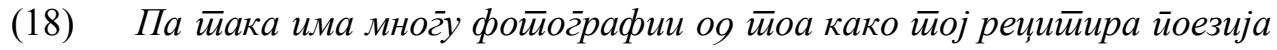

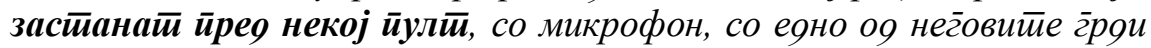
книжулиња во йрсиийе. (РБ, 8) ('додека рецитира поезија, тој е застанат пред некој пулт')

Во ексцерпираниот материјал се јавуваат, меѓу другите, следниве комбинации: лежи заяишан и исйойен, влезе йијан, йочине млая, сеяи навален

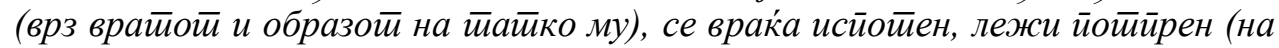

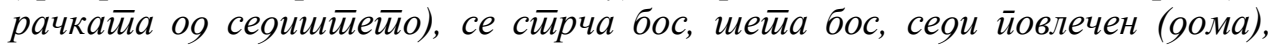

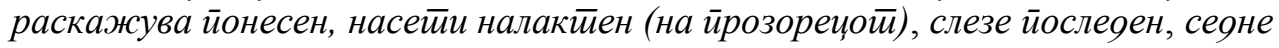
расйлакан, се разминува нем и намйурен, чийа лег̄най, gојgе йрв, се разбуяи

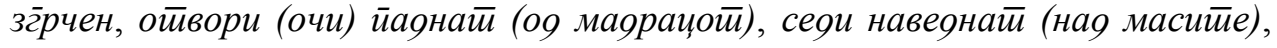
сеои сйокоен итн. 
Најчеста во таа функција е придавката сам, при што општата парафраза е 'прави нешто без придружба' (19), (20).

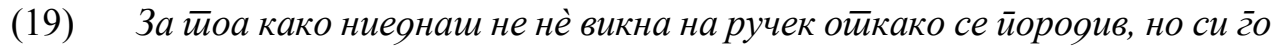
викаше Генчо gа ѝ gоаѓa сам во сабойийе. (РБ, 47) ('доаѓа, при што е сам, без придружба')

(20) Се йозоравуваме и йрооолжувам сам йо шейалишӣейо. (BМ, 62) (продожувам по шеталиштето, при што сум сам, без придружба)

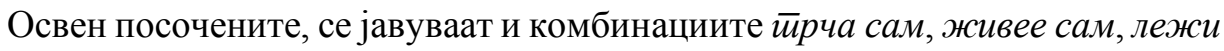
сам, оои сам, г̈леоа сам итн.

\section{3 Конструкции со каузална нијанса}

Придавката сам уште почесто се јавува во случаи каде што импликацијата е концесивна, т.е. може да се парафразира како 'прави нешто, иако нема поттик или помош од некого', односно како 'прави нешто непоттикнат или непомогнат' (21).

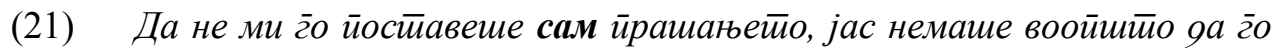
забележам йоа. (БК, 54) ('ми го постави прашањето без да го поттикнам')

Меѓу другите, се изделуваат и следниве комбинации: си найрави (вечера) сам, се научи сам, йодг̄ойви (кафе) сам, се йонуяи сам, оознае сам, се снаоѓа

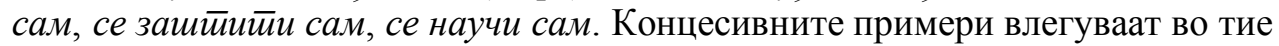
што, освен што изразуваат карактеристика паралелна на настанот, содржат и каузална нијанса. Освен концесивна (22), таа може да биде причинска (23) и условна (24). ${ }^{3}$ Каузалниот карактер на тие случаи произлегува од релацијата помеѓу примарниот и секундарниот предикат. Во таа смисла, во посочените примери се тргнува од општоприфатените принципи дека неодморен не се работи, дека разочарувањето поттикнува на напуштање на местото и дека со здруженост полесно се постигнува целта.

(22) Рабойеше неомморен. ('иако беше неодморен, работеше' / ‘додека работеше, беше неодморен')

(23) Замина разочарана. ('бидејќи беше разочарана, замина' / 'кога замина, беше разочарана')

\footnotetext{
${ }^{3}$ Николс ги разгледува условните, временските и концесивните како „околносни секундарни предикати“ (circumstantial secondary predicates) (во Himmelmann and Schultze-Berndt 2005).
} 


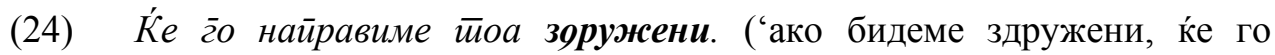
направиме тоа' / 'кога ќе го направиме тоа, ќе бидеме здружени')

Сепак, во некои контексти каузалната нијанса може да биде исклучена. Така, во (23a) е јасно дека причина за заминувањето не е разочараноста, туку некоја обврска, посочена во претходниот контекст, па карактеристиката е еднозначно паралелна на примарната предикација, без причинска импликација.

(23а) Денес мораме gа си ояи. И, намесӣо яа йонесе убав вйечайок, замина разочарана. ('кога замина, беше разочарана')

Слично на (23a), а за разлика од (24), придавскиот елемент во (24a) нема условно значење. Условот (доволно расположливо време) е посочен во претходниот контекст, а причината (избегнување поединечна критика) - во следниот, па интерпретацијата ќе биде: 'кога ќе го направиме тоа, ќе бидеме здружени - таа идеја ќе ја реализираме ако имаме доволно време, а здружени ќе бидеме за да не нѐ критикуваат поединечно'.

(24а) Ако ни остиане време, ќе г̄о найравиме йоа зоружени. Така, никој не ќе може qа нѐ крийикува йоеяинечно. ('кога ќе го направиме тоа, ќе бидеме здружени')

\section{3 Придавската секундарна предикација од аспект на информациската структура}

\section{1 Фокусирани случаи}

Во сите претходни примери, кои се најчести, придавските секундарни предикати функционираат како рема, па затоа се сместени во зоната десно од глаголскиот предикат. Од друга страна, поставувањето на секундарните предикати во зоната лево од предикатот (која е поневообичаена за ремата) е во функција на фокусирање на нивниот рематски карактер. Како што посочува Кресел (Creissels 2006: 111-112), под фокусирање се подразбира истакнување, експлицитно сигнализирање на информациски најзначајниот елемент. Во (22б), (23б), (24б) и (25) тие се во функција на фокусирана рема.

(22б) Неомморен рабойеше. ('неодморен беше додека работеше')

(23б) Разочарана замина. ('разочарана беше кога замина')

(24б) Зоружени ќе г̄o найравиме ӣоа. ('здружени ќе бидеме кога ќе го направиме тоа')

(25) Весел gojge. ('весел беше кога дојде') 
Во ексцерпираниот материјал такви случаи се јавуваат (26), (27), (28), но очекувано, многу поретко од случаите во кои секундарниот предикат е десно од глаголскиот.

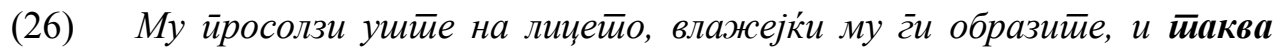
расйлакана сеяна яо нег̄о, иррео иокриенайа кошница на масайа и со

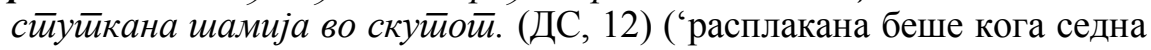
до него')

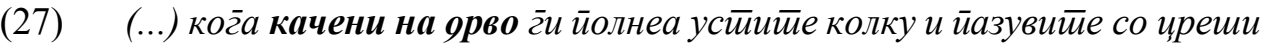
(...) (ДС, 139) ('качени на дрво беа додека ги полнеа устите и пазувите со цреши')

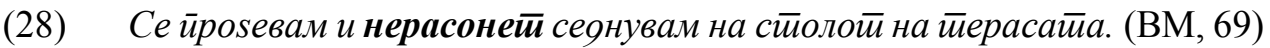
('нерасонет сум додека седнувам на столот')

\section{2 Конструкции неинтегрирани во прозодиската структура}

Сите претходни примери се со секундарни предикати интегрирани, вклопени во прозодиската структура на исказот, од кои секоја може да се реализира и во неинтегрирана варијанта, т.е. со полупауза, која во пишуваниот јазик се бележи со запирка (22в)-(24г).

(22в) Рабойеше, неомморен.

(22г) Неомморен, рабоиете.

(23в) Замина, разочарана.

(23г) Разочарана, замина.

(24в) К̈е г̄о найравиме тиоа, зоружени.

(24г) Зоружени, ќе г̃о найравиме тиоа.

Во ексцерпираниот материјал се изделуваат голем број неинтегрирани варијанти и во зоната лево (29), (30) и во зоната десно од предикатот (31), (32).

(29) Тони им се израяува и ценйлеменски иррво мене ми сйави неколку йарчињ а во чинијайа, и йака насмеан, се обияе gа иे сйави и неколку на Ирена (...) (РБ, 110) ('се обиде да ѝ стави и неколку на Ирена, при што беше насмеан')

(30) Така, йо малку луйа на себеси а йовеќе на Горан, Лияа излезе оя gома. (ДС, 149) ('кога излезе од дома, Лида беше лута' / 'бидејќи беше лута, Лида излезе од дома') 


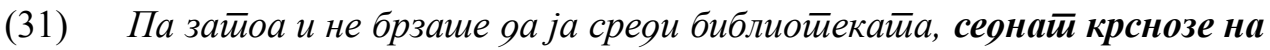
иоооой со ойворена книга во скуйой (...) (ДС, 49) ('не брзаше да ја среди библиотеката, при што беше седнат крснозе')

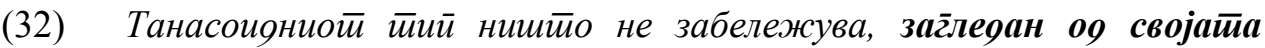

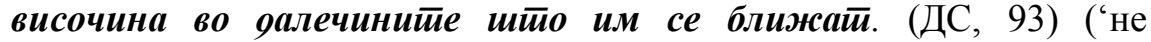
забележува ништо, при што е загледан во далечините' / 'бидејќи е загледан во далечините, не забележува ништо')

За разлика од интегрираните варијанти во зоната лево од предикатот, од типот на (28), кои се, како што беше посочено, поретки, неинтегрираните, од типот на (29), се сосема вообичаени.

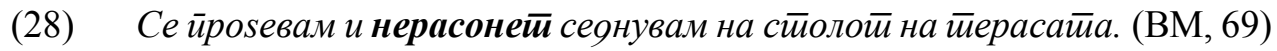

(29) Тони им се израяува и иенитлеменски ирво мене ми сииави неколку

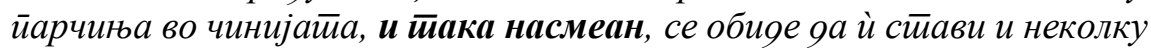
на Ирена (...) (РБ, 110)

Причина за таа разлика е тоа што неинтегрираните варијанти се надвор од информациското јадро, т.е. не функционираат ни како тема ни како рема во вистинска смисла (Combettes 1998: 64-68), па не се врзани ни за тематската (левата) ни за рематската (десната) позиција, т.е. слободно се јавуваат во двете. На пример, што се однесува на (23) и (23б), во кои рема е разочарана, ако се претпостави контекст во кој функционираат како одговор на прашањето Каква беше ког̄а замина?, предикатот, бидејќи се подразбира, може и да се изостави (т.е. одговорот да гласи само: разочарана). Во (23в) и (23г) информациско јадро е глаголскиот предикат, па може да се изостави придавскиот елемент (сп. ibid., 64-68).

(23) Замина разочарана.

(23б) Разочарана замина.

(23в) Замина, разочарана.

(23г) Разочарана, замина.

Илустрација за таа разлика се двојките (23д) и (23ѓ), од една страна, и (23e) и (23ж), од друга. Варијантата (23ŕ), која е (за разлика од 23 д) исклучена затоа што е противречна, покажува дека интегрираниот елемент е неопходен дел од исказот. Од друга страна, (23ж), која е (како и 23e) можна, покажува дека неинтегрираниот е секундарен, т.е. може и да се изостави.

(23д) Сиие заминаа заяоволни, само йаа замина разочарана.

(23ѓ) *Сӣе заминаа заяоволни, само йаа замина. 


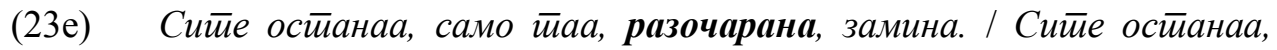
само йаа замина, разочарана.

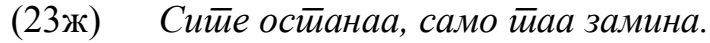

Како што се согледува, придавскиот елемент може да биде контрастиран само кога е интегриран (23д), а не и неинтегриран (233).

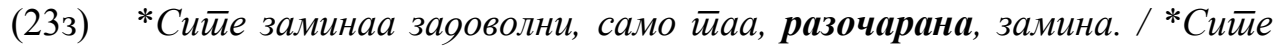
заминаа заяоволни, само йаа замина, разочарана.

Добра илустрација за разликата е и примерот (33), каде што, поради неинтегрираноста, нема импликации дали е карактеристиката врзана за субјектот само во интервалот на настанот на главниот предикат ('во тој момент, Марија уште лежеше, при што беше свртена кон sидот') или и претходно ('Марија уште лежеше, при што беше свртена кон sидот, а во таква положба беше и претходно'). За интегрираната варијанта (33a) е можно само второто толкување.

Марија уийе лежеше, сврӣена кон sияой. (ДС, 77)

(33а) Марија уийе лежеше сврӣена кон sиоой.

Во тој поглед, Ноели (Noailly 1999: 115-117) и Комбет (Combettes 1998: 13) укажуваат на разликата во поглед на негацијата. Во интегрираните варијанти таа го засега секундарниот предикат (33б), а во неинтегрираните - примарниот (33в).

(33б) Марија не лежеше сврӣена кон sияой. ('Марија лежеше, но не беше свртена кон мидот')

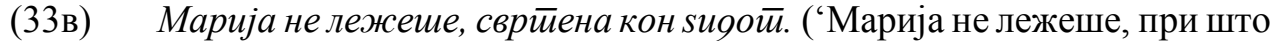
беше свртена кон зидот')

\section{3 Конструкции со карактеристики што го опфаќаат носителот во интервал многу поширок од тој на настанот на примарната предикација}

Во сите претходни примери се изразуваат карактеристики фокусирани на носителот во интервалот на настанот на примарната предикација. Од друга страна, се изделуваат карактеристиките што го опфаќаат носителот во многу поширок интервал (кои му се иманентни), па не се вклопуваат во случаите со актуелни атрибути. На пример, за разлика од карактеристиката разочарана, од која носителот може да се отуѓи непосредно по настанот, карактерис-

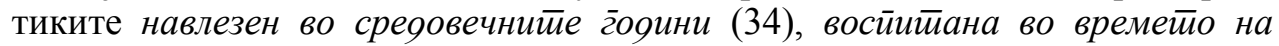


романйичарскиой соиијализам (35) и мал йо стиава (36) се врзуваат за него независно од примарната предикација, т.е. многу подолготрајно.

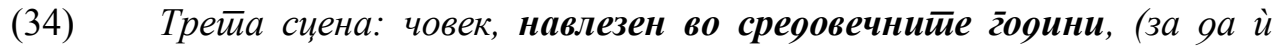

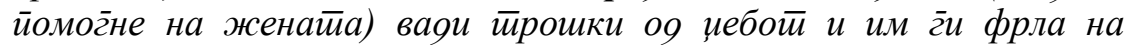
гулабийе gа се соберай. (БК, 9) ('човек, кој е навлезен во средовечните години, вади трошки од џебот')

(35) Алуяирајќи на Дано, се расйраваа околу т̄оа шӣо е ӣойрво, „,йолезен

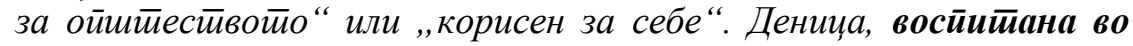
времейо на романииичарскиой социјализам, се застиаиуваше за

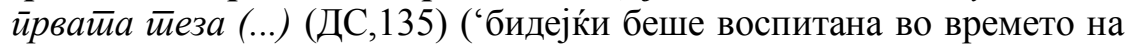
романтичарскиот социјализам, Деница се застапуваше за првата теза')

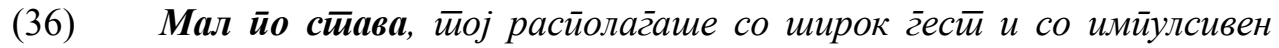
барийон. (БК, 111) ('иако беше мал по става, тој располагаше со широк гест')

Тие конструкции може да се толкуваат само во согласност со парафразите покрај примерите. Интерпретациите 'додека вади трошки, тој е навлезен во средовечните години', 'додека се застапуваше за првата теза, Деница беше воспитана во времето на романтичарскиот социјализам' и 'додека располагаше со широк гест, тој беше мал по става', се разбира, се исклучени.

Како што покажуваат примерите, тие придавски елементи може да се реализираат и во постпозиција (34), (35) и во препозиција (36) во однос на носителот. Бидејќи се дел од именската синтагма (како нерестриктивни модификатори), не може да се реализираат интегрирано во прозодиската структура на исказот (34a), (35a), (36a), што е разлика во споредба со актуелните атрибути.

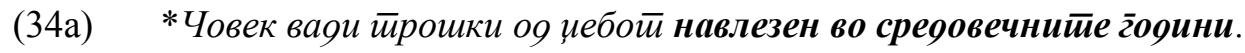

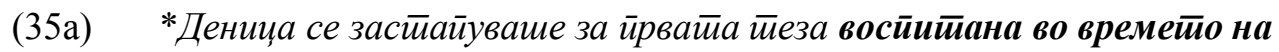
романйичарскиой социјализам.

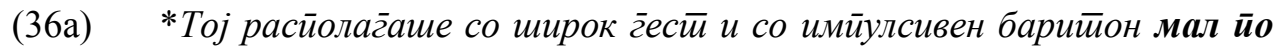
сйива.

Од друга страна, во расположливите примери не се јавува ниту една конструкција што изразува иманентна карактеристика во позиција посредна во однос на носителот, а варијантите (34б), (35б), (36б) се крајно дискутабилни.

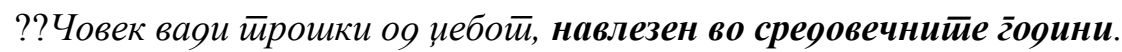




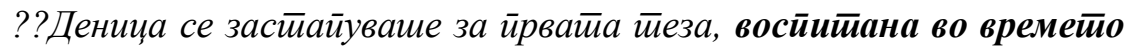
на романииичарскиой социјализам.

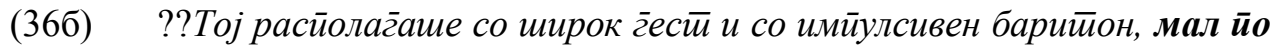
сийава.

За да се утврди степенот на прифатливост, на 28 испитаници им беа понудени примерите (37), (38) и (39), од кои првиот е без каузална нијанса, вториот - причински, а третиот - концесивен. Некаузалниот е оценет како апсолутно прифатлив од двајца испитаници, како прифатлив само во некои ситуации - од 13, а како апсолутно неприфатлив - исто така од 13. Причинскиот е оценет како апсолутно прифатлив од 14, како прифатлив само во некои ситуации - од 6 , а како апсолутно неприфатлив - од 8. Концесивниот е оценет како апсолутно прифатлив од 7, како прифатлив само во некои ситуации - од 9, а како апсолутно неприфатлив - од $12 .{ }^{4}$

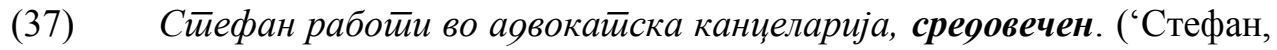
кој е средовечен, работи во адвокатска канцеларија')

(38) Иван ја осуяи нейравgайа, секог̄аш ирринцийиелен. ('бидејќи е секогаш принципиелен, Иван ја осуди неправдата')

Алексаноар ја ирремолча нейравяайа, секог̄аш иринцийиелен. ('иако е секогаш принципиелен, Александар ја премолча неправдата')

Според тоа, актуелните атрибути (депиктивните секундарни предикати) се пофлексибилни од конструкциите што изразуваат долготрајни карактеристики, во смисла на тоа дека се реализираат и интегрирано и неинтегрирано. Сепак, како што беше посочено, таа флексибилност не е неограничена. Кога се неинтегрирани, се јавуваат често и во зоната десно и во зоната лево од предикатот. Од друга страна, кога се интегрирани, исклучително ретко се јавуваат во зоната лево од предикатот, т.е. како фокусирана рема. Фреквенциската хиерархија во ексцерпираните примери е сумирана во варијантите (40), (40а), (40б), (40в).

(40) Aъа gојяе наврнайа.

(40а) Аъа gојое, наврнайа.

(40б) Наврнайа, Ања gојgе.

(40в) Наврнайа Aъа gојge.

\footnotetext{
${ }^{4}$ Маренго (Marengo 2011: 26) разгледува во францускиот јазик пример со причинско значење и го оценува како неприфатлив.
} 
Варијантата (40) е најчеста, но варијантите (40а) и (40б), кои се речиси рамномерно чести една со друга, се кумулативно почести од неа, а варијантата (40в) е најретка.

\section{4 Заклучни белешки}

Како секундарни предикати, придавките што се однесуваат на субјектот може да влезат во неколку основни семантички релации со примарната предикација: временски паралелна без дополнителни, каузални нијанси, од една страна, и временски паралелна со причинска, концесивна или условна нијанса, од друга. Сите влегуваат во сферата на т.н. актуелен атрубут (депиктивен секундарен предикат). Придавските елементи со сите посочени значења може да ги заземат позициите и во зоната лево и во зоната десно од предикатот. Сепак, за варијантите интегрирани во прозодиската структура на исказот, кои функционираат како рема, е вообичаена позицијата десно од предикатот, а во левата зона, каде што се јавуваат како фокусирана рема, се многу поретки. Од друга страна, неинтегрираните варијанти се надвор од информациското јадро, па не се врзани ни за тематската (левата) ни за рематската (десната) позиција, т.е. слободно се јавуваат во двете. Тие се информациски секундарни, па може и да се изостават, што е разлика во споредба со интегрираните, кои се неопходен дел од исказот, а може да бидат и контрастирани.

За разлика од придавките што изразуваат карактеристика актуелна во интервалот на настанот на примарната предикација, кои може да функционираат и како интегрирани и како неинтегрирани, придавките што изразуваат карактеристики што го опфаќаат носителот во многу поширок интервал (кои му се иманентни) се јавуваат само како неинтегрирани (ако се остават настрана случаите во кои се рестриктивни модификатори). Освен тоа, независно од тоа дали се интегрирани или неинтегрирани, придавките што изразуваат карактеристики паралелни на настанот не мора да бидат во позиција непосредна во однос на носителот. Напротив, конструкциите десно од предикатот што се однесуваат на субјект лево од предикатот се дури и најчести. Од друга страна, барем според расположливите примери, придавските конструкции што изразуваат долготрајни карактеристики се секогаш во директна врска со носителот.

\section{Библиографија}

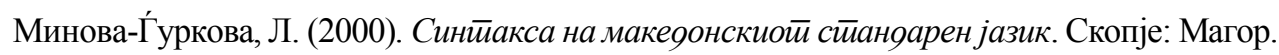

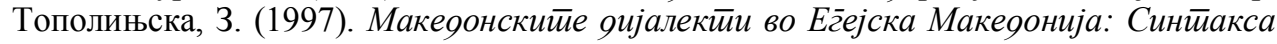
$(\bar{u} .2)$. Скопје: МАНУ.

Combettes, B. (1998). Les constructions détachées en français. Paris: Édition Ophrys. 
Creissels, D. (2006). Syntaxe générale une introduction typologique 1 (catégories et constructions). Paris: Hermes Science Publications.

Himmelmann, N. P. and Schultze-Berndt, E. (2005). Issues in the Syntax and Semantics of Participant oriented adjuncts: an Introduction. In N. P. Himmelmann and E. SchultzeBerndt (eds.). Secondary predication and adverbial modification: The typology of depictives, 1-67. Oxford: Oxford University Press.

Maingueneau, D. (2014). La syntaxe du français. Paris: Hachette Supérieur.

Marengo, S. (2011). Les adjectifs jamais attributs: syntaxe et sémantique des adjectifs constructeurs de la référence. Bruxelles: De Boeck-Duculot.

Noailly, M. (1999). L'adjectif en français. Paris: Édition Ophrys.

Riegel, M., Pellat, J.C. et Rioul, R. (2014). Grammaire méthodique du français. (5e éd.) Paris: Presses Universitaires de France.

\section{Извори}

Бужаровска, Р. (2017). Мојой маж. Скопје: Или-Или.

Конески, Б. (1988). Дневник ӣo многуу г̄ояини. Скопје: Македонска книга.

Мартиновски, В. (2016). Небо без sвезои (хаибуни). Скопје: Или-Или.

Солев, Д. (1998). Мрйва тирка. Скопје: Култура. 